\title{
A Comparative Study on the Effect of Household Water Treatment on Diarrhoea Morbidity among Under-Fives in Plateau State, Nigeria Using Two Treatment Modalities
}

\author{
${ }^{1}$ Elizabeth Onyi Okoh ${ }^{*},{ }^{2}$ Esther Awazzi Envuladu, ${ }^{3}$ Chundung Asabe Miner, ${ }^{4}$ Amina Mohammed, \\ ${ }^{5}$ Gloria Nengi Ode, ${ }^{6}$ Ayuba Ibrahim Zoakah \\ ${ }^{1,2,3,5,6}$ Department of Community Medicine, College of Health Sciences, University of Jos, Plateau State, \\ Nigeria \\ ${ }^{1,2,3,6}$ Department of Community Medicine, Jos University Teaching Hospital, Plateau State, Nigeria \\ ${ }^{4}$ Department of Community Medicine, College of Medicine, Gombe State University, Gombe Nigeria \\ ${ }^{4}$ Department of Community Medicine, Federal Teaching Hospital Gombe. Gombe Nigeria
}

\begin{abstract}
Background: Consumption of unsafe water contributes to diarrhoeal burden in sub-Sahara Africa. This burden can be reduced by simple and affordable methods of household water treatment. The study aims at comparing the effect of two of such methods on diarrheal burden among under-fives in rural communities of Plateau State.

Methodology: A community-based quasi experimental study was conducted among 202 underfivecaregiver pairs in two selected rural communities of Plateau State, involving household water treatment with flocculant-disinfectant powder in intervention group and sodium hypochlorite solution in control group. History of diarrhoea before intervention, at 2 weekly intervals during the intervention and after intervention was assessed. Data obtained was analyzed using SPSS version 23. Prevalence and incidence of diarrhoea were calculated and compared among the two groups.

Result: Diarrhoea prevalence at pre-intervention was $19.6 \%$ in flocculant-disinfectant group and $17.0 \%$ in sodium hypochlorite group. At post intervention, the prevalence reduced significantly by $94.7 \%(19.6 \%$ to $1 \%$ ) in intervention group and by $76.5 \%$ (17\% to $4.2 \%)$ in control group. There was no statistically significant difference in the prevalence of diarrhoea between the two groups. However, diarrhoea incidence in the sodium hypochlorite group (1.12 episode per child per year) was significantly higher than the incidence in the flocculant-disinfectant group (0.59 episodes per child per year) with a risk-ratio of 1.93 (95\% CI: 1.037 - 3.703).

Conclusion: Household water treatment with flocculant-disinfectant reduced diarrhoea burden better than sodium hypochlorite. This technology should be made more available and assessible to rural communities where diarrhea burden is high.
\end{abstract}

Keywords: Household water treatment, diarrhoea morbidity, flocculant-disinfectant, sodium hypochlorite

\section{Introduction}

Diarrhoea is a health condition which is characterized by decreased consistency and increased number of stools. ${ }^{1}$ Children especially under-fives, are particularly vulnerable to diarrhoeal diseases and their lifethreatening complications. Among under-fives globally, diarrhea remains the second leading cause of death, second only to acute respiratory infections, accounting for 1 in 9 child deaths ${ }^{2}$ and caused up to $8 \%$ of under-five deaths in 2017. ${ }^{3}$ About 1,300 children and 480,000 children die from diarrhoea on a daily and yearly basis respectively. Most under-five deaths from diarrhea are observed in South Asia and sub-Saharan Africa. ${ }^{3,4}$ In Nigeria, up to 194,000 lives are lost annually from diarrhoea, a figure which is second highest in the world, after India. ${ }^{5}$ Its prevalence among under-fives in Nigeria continues to increase as it increased from $10 \%$ in $2013^{6}$ to $13 \%$ in $2018 .^{7}$ Similarly in Plateau State, diarrhoeal prevalence increased from 5.6\% in $2013^{6}$ to $13.3 \%$ in $2018 .^{7}$ 
Consumption of unsafe drinking water is one of the routes through which diarrhoeal pathogens can be transmitted faeco-orally. Globally, 785 million people lack access to improved drinking water sources and over 2 billion people drink water from sources that are contaminated with faeces. ${ }^{8}$ About $88 \%$ of the 4 billion cases of diarrhoeal disease that occur annually are as a result of unsafe drinking water, along with poor sanitation and hygiene. ${ }^{9}$ These also account for about $60 \%$ of diarrhoeal deaths.

Waterborne diseases including diarrhoea, exact a heavy burden for both individuals and the public health care system in developing countries. This burden can be prevented or significantly reduced by the use of appropriate, simple, acceptable and affordable point-of-use/household water treatment methods which have been shown to reduce diarrheal diseases by up to $50-70 \%$ even in resource-limited areas. ${ }^{9}$ One of such methods is the use of chlorine-based disinfectants commonly available as sodium hypochlorite solution/powders which inactivate bacteria and some viruses. ${ }^{10}$ Another technology suitable for resourcelimited settings which is quite new in this part of the country, is the combination of chlorination and flocculation using flocculant-disinfectant powders, granules or tablets which has an added advantage against pathogens hidden within flocs or particles in dirty water. ${ }^{1,11}$

This study aims to determine and compare the effect of household water treatment on diarrhoea morbidity among under-fives in rural communities of Plateau State using the two treatment modalities: use of combined flocculant-disinfectant (flocculation and disinfection) and sodium hypochlorite solution (disinfection alone).

\section{Materials And Methods}

Study Area: This study was carried out in selected communities of Plateau State, located in the North Central zone of Nigeria, West Africa. Plateau State is divided into 17 Local Government Areas (LGAs). Sixty nine percent of inhabitants live in rural areas, while $31 \%$ live in urban areas. The State has abundant surface and ground water resources, especially during the rainy seasons which peaks within the months of July and August. ${ }^{12}$

Study Design and population: The study was a community-based quasi-experimental study conducted among under-fives and their adult female primary caregivers involving the use of the more familiar sodium hypochlorite solution (disinfectant alone) and newer combination of flocculant-disinfectant powder in two selected rural communities of Plateau State.

Sample size and sampling Technique: A minimum sample size of 89 was calculated [using the formula: $n$ $\left.=\left(Z_{\alpha}+Z_{\beta}\right)^{2} 2 p(1-p) / d^{2}\right]$ for each community. But participants selected ended up being 100 in group $A$ and 102 in group B using a multi-stage sampling technique. Bassa and Jos-East LGAs were selected from the 17 LGAs in the State which was followed by selection of wards and communities, all using Simple Random Sampling (SRS) by balloting. The two communities selected were studied as clusters. For households with more than one under-five, SRS by balloting was used to select one under-five. Foda Fobur community was selected as intervention group A and Igbak community as control group B.

Study instruments: Instruments used for data collection included a semi- structured interviewer administered questionnaire (which collected data on socio-demographic characteristics, history of diarrhoea, water management practices and factors affecting diarrhoea), an observational checklist, basinet and bathroom weighing scales, and laboratory instruments for water collection and analysis.

Data collection method: Recruitment and training of research assistance for data collection was done. Advocacy visits to the two LGA Chairmen, district heads, ward heads and community heads were carried out and their permission obtained. Baseline data was collected from the respondents after obtaining written informed consent. A two-week history of diarrhoea among under-fives was obtained and water samples were collected from each household for microbiological analysis.

The intervention comprised of health education (on HWT, causes and prevention of diarrhoea) and household treatment of drinking water with combined flocculant-disinfectant for the study participants in intervention group A while the participants in the control group B received disinfectant alone as sodium hypochlorite solution for their household drinking water treatment. Participants were followed for 12 weeks with 2-weekly assessment of diarrhoea. At post-intervention, tools used at baseline were also used to collect 
information from participants in their households which included history of diarrhoea and drinking water analysis.

Data management and analysis: Data was processed and analyzed using the SPSS version 23 statistical package. Quantitative variables were summarized using mean and standard deviation while qualitative variables were summarized using tables and charts. Logistic regression was done to identify exposure variables that predicted diarrhoea among the under-fives after previously being subjected to bivariate analysis.

Diarrhoea was defined as the passage of 3 or more loose stools over a 24-hour period in an under-five or an increase in stool frequency or liquidity that is considered abnormal for the child. A fresh episode was defined as diarrhoea occurring after a two days period free of diarrhoea. Two-week prevalence, cumulative incidence of diarrhoea (calculated as number of diarrhea episodes during the period / total number of underfives at the start of the period X 100) and incidence density of diarrhoea (number of diarrhoea episodes during study period / total number of person-time observed X 1000) were calculated for each group. A risk ratio (incidence in control group / incidence in intervention group) was also calculated.

Ethical consideration: Ethical approval for the study was obtained from the Human and Research Ethics Committee of Jos University Teaching Hospital. Verbal and written informed consent were obtained from participants and confidentiality was ensured.

Limitation of the study: There could have been recall bias in measuring responses of participants, especially in reporting diarrhoea. However, it is hoped that a recall period of two weeks is a reasonable period in reporting disease morbidity before significant bias sets in.

\section{Results}

\section{Household, child and caregiver characteristics}

The participants (child-caregiver pair) enrolled in the study were 102 in groups A and 100 in B. There was an attrition rate of $1.9 \%$ and $4 \%$ respectively. The mean ages of the caregivers were $34.0 \pm 12.9$ years and $31.0 \pm 11.6$ years while the mean ages of the under-fives were $31.4 \pm 15.7$ and $33.9 \pm 17.5$ months in groups $\mathrm{A}$ and $\mathrm{B}$ respectively. These showed no statistically significant differences.

Tables 1 and 2 showed that the household and personal characteristics of participants in both groups were largely similar.

Table 1: Baseline socio-demographic characteristics of caregivers and household

\begin{tabular}{|c|c|c|c|c|c|c|c|}
\hline \multirow[b]{2}{*}{ Characteristics } & \multicolumn{2}{|c|}{$\begin{array}{c}\text { Group A } \\
(\mathbf{n}=\mathbf{1 0 2})\end{array}$} & \multicolumn{2}{|c|}{$\begin{array}{l}\text { Group B } \\
(\mathbf{n}=\mathbf{1 0 0})\end{array}$} & \multirow[b]{2}{*}{$\begin{array}{l}\chi^{2} \\
\text { value }\end{array}$} & \multirow[b]{2}{*}{ df } & \multirow[b]{2}{*}{ P- } \\
\hline & Freq & $\%$ & Freq & $\%$ & & & \\
\hline $\begin{array}{l}\text { Marital status } \\
\text { Currently married }\end{array}$ & 84 & 82.4 & 91 & 91.0 & & & \\
\hline $\begin{array}{l}\text { Not currently } \\
\text { married }\end{array}$ & 18 & 17.6 & 9 & 9.0 & 3.244 & 1 & 0.072 \\
\hline $\begin{array}{l}\text { Ethnicity } \\
\text { Iindigenous } \\
\text { tribes } \\
\text { Non indigenous } \\
\text { Tribes }\end{array}$ & $\begin{array}{l}82 \\
80.4 \\
20\end{array}$ & 19.6 & $\begin{array}{l}90 \\
90.0 \\
10 \\
10.0\end{array}$ & & 3.686 & 1 & 0.239 \\
\hline $\begin{array}{l}\text { Level of education } \\
\text { No formal education } \\
\text { Primary } \\
\text { Secondary } \\
\text { Tertiary }\end{array}$ & $\begin{array}{l}16 \\
39 \\
38.2 \\
38 \\
37.3\end{array}$ & 15.7 & $\begin{array}{r}10 \\
52 \\
35 \\
3\end{array}$ & $\begin{array}{r}10.0 \\
52.0 \\
35.0 \\
3.0\end{array}$ & 6.346 & 3 & 0.096 \\
\hline
\end{tabular}




\begin{tabular}{|c|c|c|c|c|c|c|c|}
\hline & $\begin{array}{l}9 \\
8.8\end{array}$ & & & & & & \\
\hline $\begin{array}{l}\text { Occupation } \\
\text { None/house wife } \\
\text { Petty trading } \\
\text { Farming } \\
\text { Artisan } \\
\text { Others }\end{array}$ & $\begin{array}{l}29 \\
28.4 \\
28 \\
27.5 \\
31 \\
8 \\
7.8 \\
6 \\
5.9\end{array}$ & 30.4 & $\begin{array}{l}14 \\
14.0 \\
26 \\
26.0 \\
44 \\
44.0 \\
13 \\
13.0 \\
3 \\
3.0\end{array}$ & & $\begin{array}{r}9.732 \\
\mathbf{0 . 0 4 5 *}\end{array}$ & & 4 \\
\hline $\begin{array}{l}\text { Household monthly } \\
\text { income (Naira) } \\
<5000 \\
5000-20000 \\
21000-50000 \\
\geq 51000\end{array}$ & $\begin{array}{l}10 \\
58 \\
25 \\
24.5 \\
9\end{array}$ & $\begin{array}{r}9.8 \\
56.9 \\
\\
6.9\end{array}$ & $\begin{array}{l}14 \\
14.0 \\
56 \\
56.0 \\
24 \\
24.0 \\
6 \\
6.0 \\
\end{array}$ & & 1.302 & 3 & 0.729 \\
\hline $\begin{array}{l}\text { Number of persons } \\
\text { in household } \\
1-5 \text { persons } \\
\geq 6 \text { persons }\end{array}$ & $\begin{array}{l}51 \\
51\end{array}$ & $\begin{array}{l}50.0 \\
50.0\end{array}$ & $\begin{array}{l}39 \\
39.0 \\
61 \\
61.0\end{array}$ & & 2.473 & 1 & 0.116 \\
\hline $\begin{array}{l}\text { Number of under- } \\
\text { fives in household } \\
1 \text { or } 2 \\
\geq 3\end{array}$ & $\begin{array}{l}91 \\
11\end{array}$ & $\begin{array}{l}89.2 \\
10.8\end{array}$ & $\begin{array}{r}94 \\
6\end{array}$ & $\begin{array}{r}94.0 \\
6.0\end{array}$ & $0.221^{1.500}$ & & 1 \\
\hline $\begin{array}{l}\text { Care-giver } \\
\text { under-five } \\
\text { Mother } \\
\text { Grandmother } \\
\text { Aunt/neighbor }\end{array}$ & $\begin{array}{l}88 \\
86.3 \\
12 \\
11.8 \\
2\end{array}$ & 2.0 & $\begin{array}{l}90 \\
90.0 \\
8 \\
8.0 \\
2 \\
2.0 \\
\end{array}$ & & - & & - \\
\hline
\end{tabular}

$*=$ Fisher's exact

Table 2: Personal characteristics of under-five

\begin{tabular}{|c|c|c|c|c|c|}
\hline $\begin{array}{l}\text { Child } \\
\text { Characteristics }\end{array}$ & $\begin{array}{l}\text { Group } \\
\text { A(n=102) } \\
\text { Freq }(\%)\end{array}$ & $\begin{array}{l}\text { Group } \\
(n=100) \\
\text { Freq }(\%)\end{array}$ & $\begin{array}{c}\chi^{2} \\
\text { value }\end{array}$ & df & P- \\
\hline $\begin{array}{l}\text { Age of child } \\
\leq 24 \text { months } \\
>24 \text { months }\end{array}$ & $\begin{array}{l}39(38.2) \\
63(61.8)\end{array}$ & $\begin{array}{l}39(39.0) \\
61(61.0)\end{array}$ & $\begin{array}{l}0.01 \\
0.911\end{array}$ & & 1 \\
\hline $\begin{array}{c}\text { Birth order } \\
1^{\text {st }}-3^{\text {rd }}\end{array}$ & $68(66.7)$ & $65(65.0)$ & & & \\
\hline
\end{tabular}




\begin{tabular}{|c|c|c|c|c|}
\hline$\geq 4^{\text {th }}$ & $34(33.3)$ & $35(35.0)$ & $\begin{array}{l}0.06 \\
0.803\end{array}$ & 1 \\
\hline $\begin{array}{l}\text { School enrolment } \\
\text { In school } \\
\text { Not in school }\end{array}$ & $\begin{array}{l}58(56.9) \\
44(43.10\end{array}$ & $\begin{array}{l}44(44.0) \\
56(56.0)\end{array}$ & $\begin{array}{l}3.33 \\
0.068\end{array}$ & 1 \\
\hline $\begin{array}{l}\text { Exclusively } \\
\text { breastfed } \\
\text { No } \\
\text { Yes } \\
\end{array}$ & $\begin{array}{cc}3 & (2.9) \\
99 & (97.1)\end{array}$ & $\begin{array}{c}4(4.0) \\
96(96.0)\end{array}$ & $\begin{array}{l}0.17 \\
0.681\end{array}$ & 1 \\
\hline $\begin{array}{l}\text { Fully immunized } \\
\text { Yes } \\
\text { No } \\
\text { No idea }\end{array}$ & $\begin{array}{rr}81 & (79.4) \\
17 & (16.7) \\
4 & (3.9) \\
\end{array}$ & $\begin{array}{rr}90 & (90.0) \\
6 & (6.0) \\
4 & (4.0) \\
\end{array}$ & - $0.051 *$ & - \\
\hline $\begin{array}{c}\text { Weight for age } \\
\leq-2 \text { Z-scores } \\
>-2 \text { Z-scores }\end{array}$ & $\begin{array}{rr}3 & (2.9) \\
99(97.1)\end{array}$ & $\begin{array}{rr}2 & (2.0) \\
98(98.0)\end{array}$ & $\begin{array}{l}0.18 \\
0.668 \\
\end{array}$ & 1 \\
\hline $\begin{array}{r}\text { Height for age } \\
\leq-2 \text { Z-scores } \\
>-2 \text { Z-scores }\end{array}$ & $\begin{array}{rr}1 & (1.0) \\
101(99.0)\end{array}$ & $\begin{array}{rr}2 & (2.0) \\
98(98.0)\end{array}$ & $\begin{array}{l}0.36 \\
0.550\end{array}$ & 1 \\
\hline
\end{tabular}

$*=$ Fisher's exact

\section{Household drinking water quality}

As depicted in table 3, the proportions of households with E. coli contamination of water in the two groups were comparable before intervention even though more households in group A had contaminated water. There was however, a significant difference observed after intervention with group A having fewer households with contaminated water when compared with group B households.

Table 3: Comparison of drinking water contamination of households before and after intervention

\begin{tabular}{|c|c|c|c|c|}
\hline \multirow{2}{*}{$\begin{array}{l}E . \quad \text { coli } \\
\text { contamination of } \\
\text { drinking water }\end{array}$} & \multicolumn{2}{|c|}{ Before intervention } & \multicolumn{2}{|c|}{ After intervention } \\
\hline & $\begin{array}{l}\text { Group A } \\
\text { Freq }(\%)\end{array}$ & $\begin{array}{l}\text { Group B } \\
\text { Freq }(\%)\end{array}$ & $\begin{array}{l}\text { Group A } \\
\text { Freq }(\%)\end{array}$ & $\begin{array}{l}\text { Group B } \\
\text { Freq }(\%)\end{array}$ \\
\hline $\begin{array}{l}\text { E. coli } \\
\text { Absent }\end{array}$ & $26(26.0)$ & $37(38.5)$ & $88(88.0)$ & $64(66.7)$ \\
\hline Present & $74(74.0)$ & $59(61.5)$ & $12(12.0)$ & $32(33.3)$ \\
\hline & \multicolumn{2}{|c|}{$\chi^{2}=3.52 ; \mathrm{df}=1 ; \mathrm{p}=0.060$} & \multicolumn{2}{|c|}{$\chi^{2}=12.80 ; \mathrm{df}=1 ; \mathbf{p}<\mathbf{0 . 0 0 1} *$} \\
\hline
\end{tabular}

Diarrhoea prevalence and incidence

The prevalence of diarrhoea significantly reduced after intervention by $94.7 \%$ in group A (flocculantdisinfectant group) and $76.5 \%$ in group B (sodium hypochlorite group).

Table 4: Comparison of diarrhoea prevalence within each group

\begin{tabular}{|c|c|c|c|c|c|c|}
\hline \multirow[b]{2}{*}{ Diarrhoea } & \multicolumn{3}{|c|}{ Group A (post-intervention) } & \multicolumn{3}{|c|}{ Group B (post-intervention) } \\
\hline & $\begin{array}{l}\text { Absent } \\
(\% \text { of } \\
\text { total })\end{array}$ & $\begin{array}{l}\text { Present }(\% \\
\text { of total })\end{array}$ & Total & $\begin{array}{l}\text { Absent } \\
(\% \text { of } \\
\text { total })\end{array}$ & $\begin{array}{l}\text { Present }(\% \\
\text { of total })\end{array}$ & Total \\
\hline $\begin{array}{l}\text { Pre- } \\
\text { intervention } \\
\text { Absent } \\
\text { Present }\end{array}$ & $\begin{array}{l}81 \\
(81.0) \\
18(18.0\end{array}$ & $\begin{array}{ll}0 & (0.0) \\
1 & (1.0)\end{array}$ & $\begin{array}{l}81(81.0) \\
19(19.0)\end{array}$ & $\begin{array}{l}76(79.1) \\
16(16.7)\end{array}$ & $\begin{array}{ll}3 & (3.1) \\
1 & (1.0)\end{array}$ & $\begin{array}{l}79(82.3) \\
17(17.7)\end{array}$ \\
\hline
\end{tabular}




\begin{tabular}{|c|c|c|c|c|c|c|}
\hline & ) & & & & & \\
\hline \multirow[t]{2}{*}{ Total } & $\begin{array}{l}99 \\
(99.0)\end{array}$ & $1 \quad(1.0)$ & $\begin{array}{l}100 \\
(100.0)\end{array}$ & $91(94.8)$ & $4(4.1)$ & $96(100.0)$ \\
\hline & \multicolumn{3}{|c|}{ McNemar's $\mathrm{P}<0.001$} & \multicolumn{3}{|c|}{ McNemar's $\mathrm{P}=0.003$} \\
\hline $\begin{array}{l}\text { Percentage } \\
\text { reduction in } \\
\text { diarrhoea } \\
\text { prevalence }\end{array}$ & $94.7 \%$ & & & $76.5 \%$ & & \\
\hline
\end{tabular}

Diarrhoea prevalence before intervention was $19.6 \%$ in group A and $17 \%$ in group B (table 5). After intervention, the prevalence was reduced to $1 \%$ and $4 \%$ respectively in the two groups. The two groups did not statistically differ in diarrhoea prevalence before or after interventions. However, more households were diarrhoea-free in group A (99\%) compared to group B (92\%) after intervention.

Table 5: Comparison of diarrhoea prevalence between groups at pre- and post-intervention

\begin{tabular}{|c|c|c|c|c|c|c|c|c|}
\hline \multirow[b]{2}{*}{$\begin{array}{l}\text { Diarrhoea } \\
\text { Prevalence }\end{array}$} & \multicolumn{4}{|c|}{ Before intervention } & \multicolumn{4}{|c|}{ After intervention } \\
\hline & $\begin{array}{l}\text { Group A } \\
\text { Freq (\%) }\end{array}$ & $\begin{array}{l}\text { Group B } \\
\text { Freq }(\%)\end{array}$ & $\begin{array}{c}\chi^{2} \\
\text { value }\end{array}$ & P- & $\begin{array}{l}\text { Group A } \\
\text { Freq }(\%)\end{array}$ & $\begin{array}{l}\text { Group B } \\
\text { Freq }(\%)\end{array}$ & $\begin{array}{c}\chi^{2} \\
\text { value }\end{array}$ & P- \\
\hline $\begin{array}{c}\text { Diarrhoea } \\
\text { Present } \\
\text { Absent }\end{array}$ & $\begin{array}{l}20(19.6) \\
82(80.4)\end{array}$ & $\begin{array}{l}17 \\
(17.0) \\
83 \\
(83.0)\end{array}$ & $\begin{array}{l}0.23 \\
0.632\end{array}$ & & $\begin{array}{l}1(1.0) \\
99 \\
(99.0)\end{array}$ & $\begin{array}{l}4(4.2) \\
92 \\
(92.0)\end{array}$ & 192 & 0.161 \\
\hline
\end{tabular}

At post intervention, both cumulative incidence and incidence density of diarrhoea were significantly lower among under-fives in group A than B (table 6). Under-fives in control group B were found to be 93\% more likely to have diarrhoea than those in the intervention group A.

Table 6: Incidence of diarrhoea among under-fives

\begin{tabular}{|l|l|l|}
\hline Parameters & $\begin{array}{l}\text { Flocculant-disinfectant } \\
\text { Group A }\end{array}$ & $\begin{array}{l}\text { Disinfectant-only Group } \\
\text { B }\end{array}$ \\
\hline $\begin{array}{l}\text { No. of under-fives at risk at } \\
\text { baseline }\end{array}$ & 102 & 24 \\
\hline $\begin{array}{l}\text { No. of under-fives who reported } \\
\text { diarrhoea during intervention }\end{array}$ & 12 & \multicolumn{1}{|c|}{28} \\
\hline $\begin{array}{l}\text { Total No. of new episodes of } \\
\text { diarrhoea }\end{array}$ & 15 & 8246 \\
\hline Total No. of observation days & 8526 & $\begin{array}{l}0.28 \text { episodes per child in } \\
12 \text { weeks }\end{array}$ \\
\hline $\begin{array}{l}\text { Cumulative incidence in } 12 \\
\text { weeks }\end{array}$ & $\begin{array}{l}0.15 \text { episodes per child in } \\
12 \text { weeks }\end{array}$ & $\begin{array}{l}1.12 \text { episodes per child } \\
\text { per year }\end{array}$ \\
\hline Estimated Incidence per year & $\begin{array}{l}0.59 \text { episodes per child per } \\
\text { year }\end{array}$ & $\begin{array}{l}34 \text { episodes per 10,000 } \\
\text { person } \\
\text { observation }\end{array}$ \\
\hline Incidence Density & person days of observation \\
\hline Relative risk=Inc. in group B & $\begin{array}{l}1.930 \\
(95 \% \text { CI: } 1.037 \text { - 3.703) }\end{array}$ \\
\hline
\end{tabular}

\section{Predictors of diarrhoea}

After bivariate analysis was done, 5 factors in group A and 4 factors in group B were significantly associated with diarrhoea at baseline. These were further subjected to logistic regression and in group A, age of child and duration of storage of drinking water were found to be predictors of diarrhoea. However, in 
group B, marital status, method of refuse disposal and E. coli contamination of drinking water were significant predictors of diarrhoea.

Table 7: Predictors of under-five diarrhoea in groups $A$ and $B$

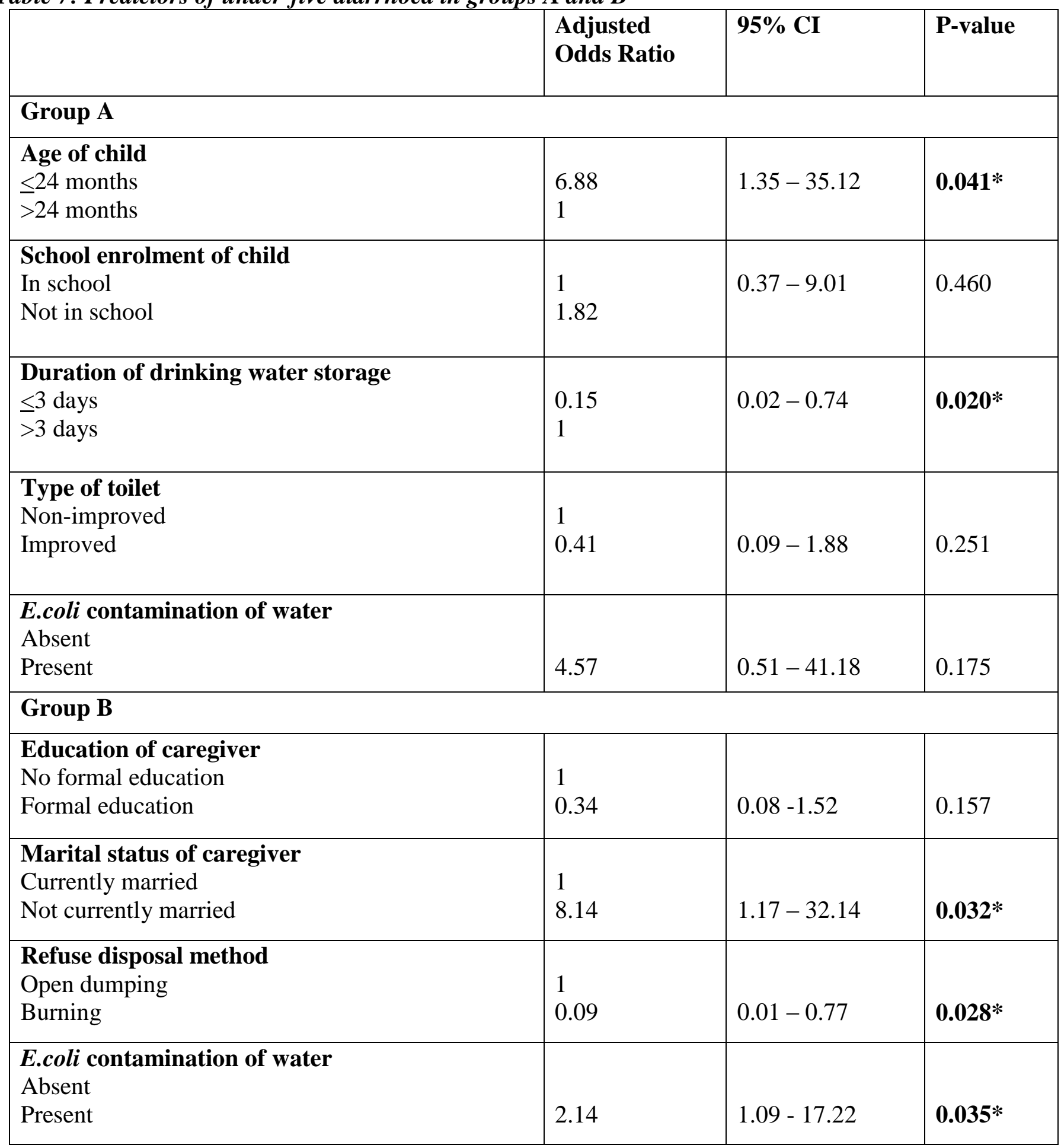

\section{Discussion}

The prevalence of diarrhoea obtained in both groups is an indication that about 1 in 5 children suffer from diarrhoeal disease in these areas. These figures are slightly higher than the national averages of $10 \%$ in $2013^{6}$ and $13 \%$ in $2018,{ }^{7}$ but closer to the prevalence of $14.8 \%$ found in another study conducted among children of rural households in Nigeria. ${ }^{7}$ The diarrhoeal prevalence of $13.3 \%$ for Plateau state as determined by the NDHS 2018 is also lower than the prevalence obtained in this study probably because of the combination of both rural and urban households in the NDHS. However, findings from studies conducted in rural areas of Ethiopia and Liberia similarly found prevalence that ranged from $19.6 \%-20.3 \%{ }^{13}$ Some studies have found higher prevalence of diarrhoea among children such as one conducted in Burundi which detected a prevalence of $32.6 \%^{14}$ and another health-facility-based Ethiopian study which found a 
prevalence of $31.7 \%{ }^{15}$ Contrary to our findings, a lower diarrhoeal prevalence of $6.1 \%$ was found among under-fives in a Tanzanian study. ${ }^{16}$ Diarrhoea is a symptom of many diseases which shows biological, geographical and seasonal variations which may explain the variations in prevalence rates found in these studies.

Both interventions were found to significantly reduce prevalence of diarrhoea in the studied communities. Although there was no statistically significant difference in diarrhoeal prevalence after intervention in the two groups, a higher reduction was observed in the flocculant-disinfectant group. Households in the flocculant-disinfectant group also had significantly lower incidence of diarrhoea when compared to households in the sodium-hypochlorite group with the sodium-hypochlorite group having almost twice the risk of childhood diarrhoea compared to flocculant-disinfectant group. Similarly, it has been demonstrated that flocculant-disinfectant reduced prevalence of diarrhoea by $83 \%$ when compared with baseline in a Liberian study ${ }^{17}$ and up to $90 \%$ reduction in other Randomized Controlled Trials. ${ }^{18,}{ }^{19}$ It was also found to have reduced prevalence of diarrhoea by $40 \%$ among infants when compared to a control group that used standard water treatment practices. ${ }^{11}$ Sodium hypochlorite and other household bleach products have also been demonstrated to reduce both prevalence and incidence of diarrhoea, but not up to the reductions observed with flocculant-disinfectant. ${ }^{20-22}$ These findings may be attributed to the fact that flocculantdisinfectant has more effect on $E$. coli and other microbes, as demonstrated in this study and other studies ${ }^{23}$, ${ }^{24}$ when compared to sodium hypochlorite. It has been found to have better effect on organisms hidden withing flocs in turbid water. However, findings from a meta-analysis has demonstrated lesser degrees of reduction for flocculant-disinfectant and sodium hypochlorite at $31 \%$ and $29 \%$ respectively. ${ }^{25}$

The first 24 months of life was found to be a significant predictor of childhood diarrhoea, accounting for over 6 times the prevalence when compared to older ages. This is corroborated by a joint report of UNICEF/WHO indicating that diarrhoeal incidence is highest in the first two years of life and declines as child advances in age. ${ }^{26}$ Similarly, diarrhoea incidence and prevalence were higher among children $6-23$ months old in studies conducted in India and Ethiopia. ${ }^{27-29}$ A study conducted in Zaria, Nigeria, particularly found the ages between 12-24 months more vulnerable to diarrhoea ${ }^{30}$ and this was also corroborated in a Tanzanian study. ${ }^{16}$

Water contamination with E. coli was also associated with increased likelihood of diarrhoea in both groups. However, this was only statistically significant in group B. Many other studies have made this observation. ${ }^{31-33}$ Verification of the microbial quality of drinking-water could be done by testing for indicator microorganisms. A reliable indicator of fecal contamination of water is E. coli ${ }^{34}$ Contamination of water with fecal organisms increases the chances of diarrhoeal diseases especially in children.

Marital status in group B was significantly associated with diarrhoea and this is similar to what was observed in an Ethiopian study. ${ }^{29}$ Being in a marital relationship was found to be protective for childhood diarrhoea probably because of the added benefit of having a father figure or a partner who can reinforce the care of the child. The two main methods of refuse disposal were open dumping and burning and in group B, open dumping was more likely to be associated with childhood diarrhoea. Refuse disposal method has also been found to significantly affect diarrhoea and other health conditions in developing regions. ${ }^{35,}{ }^{36}$ Long duration of water storage increased the risk of diarrhoea as found in group A probably due to increased frequency of handling and proliferation of micro-organisms on storage.

Although not statistically significant, school attendance of child and caregiver's lack of formal education increased the likelihood of childhood diarrhoea in groups A and B respectively. Low educational level of mothers has been shown in other studies to be associated with more frequent reporting of diarrhoea. ${ }^{37,38}$ Generally, mothers and caregivers who are educated are tend to have better access to information about prevention and management of diarrhoea. On the other hand, not being in school could be related to younger age of child which has been shown to be a significant predictor in group A.

\section{Conclusion}

The prevalence of diarrhoea among under-fives in rural households of Plateau State was found to be high and their drinking water also contaminated. The level of contamination and prevalence of diarrhoea were reduced significantly by water treatment with combined flocculant-disinfectant and sodium hypochlorite 
(disinfectant alone). Flocculant-disinfectant was also more effective in reducing the incidence of childhood diarrhoea when compared to sodium hypochlorite.

\section{Recommendation}

Water treatment with combined flocculant-disinfectant should be made available and affordable to rural households where access to improved water sources is a challenge and prevalence of childhood diarrhoea continues to rise. This technology has proven to be acceptable to rural households just like sodium hypochlorite solution. The Nigerian Government can make efforts to ensure subsidized distribution of this technology to rural households.

\section{Acknowledgement}

We wish to acknowledge the Network of Behavioural Research in Child Survival in Nigeria (NETBRECSIN) for rendering technical support for this study. A special appreciation also goes to all community leaders of the communities studied for their unflinching support and assistance rendered during the study period.

\section{Conflict Of Interest}

We declare no conflict of interest in this study. The study was solely funded by the principal researcher.

\section{References}

[1.] World Health Organization (WHO). Microbial aspects. In Guidelines for drinking water quality. 3rd ed. Geneva: WHO; 2007: pp 221-294.

[2.] Centers for Disease Control and Prevention (CDC). Global diarrhea burden. 2013 [cited 2015 Feb 12]. Available from: www.cdc.gov/healthywater/global/diarrhea-burden.html

[3.] UNICEF. Diarrhoeal disease. 2019 [cited 202017 February]. Available from: https://data.unicef.org/topic/child-health/diarrhoeal-disease/.

[4.] United Nations Children's Fund (UNICEF). Diarrhea remains a leading killer of young children, despite the availability of a simple treatment solution. 2014 [cited 2015 12th February]. Available from: www.unicef.org/child-health/diarhoeal-disease

[5.] Junaid SA and Agina SE. Sanitary survey of drinking water quality in Plateau State, Nigeria. . British Biotechnology Journal. 2014;4(12):1313-20.

[6.] National Population Commission (NPC), ICF international. Nigeria Demographic and Heath Survey 2013. Abuja, Nigeria and Maryland, USA: NPC and ICF international, 2014.

[7.] National population Commission (NPC), ICF International. Nigeria Demographic and Heath Survey. Abuja, Nigeria and Maryland, USA:: NPC and ICF international; 2018.

[8.] WHO. Drinking water 2019 [cited 2020 January 2nd]. Available from: https://www.who.int/newsroom/fact-sheets/detail/drinking-water

[9.] World Health Organization (WHO). Combating water borne diseases at the household level. Geneva: WHO; 2007: pp 1-35.

[10.] Program for Appropriate Technology in Health (PATH). Market assessment of household water products in eight African countries. 2010 [cited 2015 Feb 2]. Available from: www.path.org

[11.] Chiller TM, Mendoza CE, Lopez BM, Alvarez M, Hoekstra RM, Keswick BH, et al. Reducing diarrhoea in Guatemalan children: randomized controlled trial of flocculant-disinfectant for drinking-water. Bulletin of the World Health Organization. 2006;84(1):28-35.

[12.] Arin HB, Dung CV, Zitta WS. Groundwater supply in Jos-East Local Government Area of Plateau state, Nigeria. Journal of Environmental Science and Water Resources. 2014;3(1):001-6.

[13.] Tamiso A, Yitayal M, Awoke A. Prevalence and determinants of childhood diarrhoea among graduated households, in rural area of Shebedino District, Southern Ethiopia. Science Journal of Public Health. 2014;2(3):243-51.

[14.] Diouf K, Tabatabai P, Rudolph J, Marx M. Diarrhoea prevalence in children under five years of age in rural Burundi: an assessment of social and behavioural factors at the household level. Global Health Action. 2014;7:1-9.

[15.] Mamo A, Hailu A. Assessment of prevalence and related factors of diarrheal diseases among under-five year's children in Debrebirehan Referral Hospital, Debrebirehan Town, North Shoa zone, Amhara Region, Ethiopia. Open Access Library. 2014;1:1-14. 
[16.] Mashoto K, Malebo H, Msisiri E, Peter E. Prevalence, one week incidence and knowledge on causes of diarrhea: Household survey of under-fives and adults in Mkuranga district, Tanzania. BMC public health. 2014;14:985.

[17.] Doocy S, Burnham G. Point-of-use water treatment and diarrhoea reduction in the emergency context: an effectiveness trial in Liberia. Tropical Medicine and International Health. 2006;11(10):1542-52.

[18.] Centers for Disease Control and Prevention (CDC). Household Water Treatment: Flocculant/Disinfectant powder. 2011 [cited 2015 Mar 12]. Available from: http://blogs.washplus.org/drinkingwaterupdates/2012/04/household-water-treatmentflocculantdisinfectant-powder/

[19.] Centers for Disease Control and Prevention (CDC). Household Water Treatment Options in Developing Countries: Flocculant/Disinfectant Powder . 2008 [cited 2019 Nov 12]. Available from: https://www.cdc.gov/safewater/publications_pages/options-pur.pdf.

[20.] Sobsey MD , Handzel T, Venczel L. Chlorination ans safe storage of household drinking water in developing countries to reduce waterborne diseases. Water Sci Technol. 2003;47(3):221-8.

[21.] Quick RE, Kimura A, Thevos A, Tembo M, Shamputa I, Hutwagner L, et al. Diarrhea prevention through household-level water disinfection and safe storage in Zambia. Am J Trop Med Hyg. 2002;66(5):584-9.

[22.] Mengistie B, Berhane Y, Worku A. Household water chlorination reduces incidence of diarrhea among under-five children in rural Ethiopia: A cluster Randomized Controlled Trial. PLOS ONE. 2013;8(10):1-7.

[23.] Crump JA, Okoth GO, Slutsker L, Ogaja DO, Keswick BH, Luby SP. Effect of point-of-use disinfection, flocculation and combined flocculation-disinfection on drinking water quality in western Kenya. Journal of Applied Microbiology. 2004;97(1):225-31.

[24.] 24. Crump JA, Otieno PO, Slutsker L, Keswick BH, Rosen DH, Hoekstra RM, et al. Household based treatment of drinking water with flocculant-disiinfectant for preventing diarrhoea in areas with turbid source water in rural western Kenya: cluster randomised conttrolled trial. British Medical Journal. 2005;331(7515):478-84.

[25.] Jeffreys KG. A survey of Point of Use Household Water Treatment Options for Rural South India. Georgia: Georgia State University; 2012: pp 5-59.

[26.] World Health Organization (WHO) and United Nations Children's Fund (UNICEF). Diarrhea: why children are still dying and what can be done. New York: UNICEF/WHO; 2009.

[27.] Kumar R, Borkar R. Magnitude and determinants of diarrhea among 0-6 year's children: a cohort study from central India. International Journal Of Community Medicine And Public Health. 2018;5:5246.

[28.] Mohammed S and Tamiru D. The burden of diarrheal diseases among children under five years of age in Arba Minch District, Southern Ethiopia, and associated risk factors: A cross-sectional study. International Scholarly Research Notices. 2014;2014(654901).

[29.] Takele K, Zewotir T, Ndanguza D. Risk factors of morbidity among children under age five in Ethiopia. BMC Public Health. 2019 2019/07/15;19(1):942.

[30.] Ucheh IB, Eleojo AA, Tyoalumun K, Nanpen DM. Assessment of the incidence of diarrhea in children under 5 years at the Institute of Child Health, Banzazzau, Zaria. Annals of Nigerian Medicine. 2017;11(1):6-10.

[31.] Folarin TB, Oloruntoba EO, Ayede AI. Water quality and risk of diarrhoeal infections among children under five in Ibadan, Nigeria. African Journal of Biomedical Research. 2013;16(2):67-77.

[32.] Pirsaheb M, Sharafi K, Ahmadi E, Moradi M. Prevalence of the waterborne diseases (diarrhea, dysentery, typhoid, and hepatitis A) in West of Iran during 5 years $(2006 \& \# 8211 ; 2010)$. Annals of Tropical Medicine and Public Health. 2017 November 1, 2017;10(6):1524-8.

[33.] Luby SP, Halder AK, Huda TM, Unicomb L, Islam MS, Arnold BF, et al. Microbiological Contamination of Drinking Water Associated with Subsequent Child Diarrhea. The American journal of tropical medicine and hygiene. 2015;93(5):904-11. PubMed PMID: 26438031. Epub 10/05. eng.

[34.] Aboh EA, Giwa FJ, Giwa A. Microbiological assessment of well waters in Samaru, Zaria, Kaduna, State, Nigeria. Annals of African Medicine. 2015;14(1):32-8. 
[35.] Ayalew AM, Mekonnen WT, Abaya SW, Mekonnen ZA. Assessment of Diarrhea and Its Associated Factors in Under-Five Children among Open Defecation and Open Defecation-Free Rural Settings of Dangla District, Northwest Ethiopia. J Environ Public Health. 2018;2018:4271915-. PubMed PMID: 30275841. eng.

[36.] Ogundele OM, Rapheal OM, Abiodun AM. Effects of Municipal Waste Disposal Methods on Community Health in Ibadan - Nigeria. Polytechnica. 2018 2018/10/01;1(1):61-72.

[37.] Asfaha KF, Tesfamichael FA, Fisseha GK, Misgina KH, Weldu MG, Welehaweria NB, et al. Determinants of childhood diarrhea in Medebay Zana District, Northwest Tigray, Ethiopia: a community based unmatched case-control study. BMC Pediatrics. 2018;18(1):120.

[38.] Wilson SE, Ouédraogo CT, Prince L, Ouédraogo A, Hess SY, Rouamba N, et al. Caregiver Recognition of Childhood Diarrhea, Care Seeking Behaviors and Home Treatment Practices in Rural Burkina Faso: A Cross-Sectional Survey. PLOS ONE. 2012;7(3):e33273. 